\title{
Advisory Councils For Business Colleges: Composition And Utilization
}

Dee Ann Ellingson, University of North Dakota, USA

Dennis J. Elbert, University of North Dakota, USA

Steven Moser, University of North Dakota, USA

\begin{abstract}
A major challenge facing business colleges is keeping up with the rapid changes in the business world. Business advisory councils provide an important link between business colleges and the business world. This study was conducted to gather data on the composition and utilization of these councils. The results reveal that there is widespread use of advisory councils by business colleges. The most commonly discussed issues by advisory councils were those dealing with administrative issues and student concerns while faculty issues were the least discussed. Advisory councils were also perceived as being most effective in addressing administrative and studentrelated issues.
\end{abstract}

Keywords: advisory council, advisory board, business college

\section{INTRODUCTION}

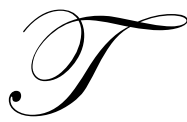

he world of business is changing at a rapid pace. At the same time, universities and consequently, colleges of business are under pressure to prepare students for this changing and challenging world with constrained resources, to do more with less. The Association to Advance Collegiate Schools of Business International (AACSB, 2000) expressed it this way:

The business world has never been more competitive, demanding and volatile than it is today. And it has never moved so fast. Business schools are the first to admit that they can 't begin to keep up without valuable direct links to the realities of that world...

How can higher education in business forge a direct link to the "real world" of business? The AACSB (2000) goes on to address this issue:

That valuable connect lies in advisory boards. These groups of executives work closely with school leadership to help bring relevance to the curriculum and the classroom and to champion the school to prospective donors and students, to business colleagues and to the community.

The AACSB has championed the use of advisory boards through continuing seminars regarding effective use of these boards, currently being offered twice per year (see aacsb.edu/conferences/events/seminars.asp).

In a recent AACSB update regarding the use of advisory boards (AACSB, 2007), the demands on advisory boards continue to grow as institutions ask for additional service and input. There are also an increasing number of boards present at business schools serving a variety of functions.

A business advisory council can provide a number of resources to the college, including assisting in strategic planning and mission development, providing counsel on administrative issues, financial support and fundraising, networking and relations with external constituencies such as alumni and the community, student internships and placement, curriculum and program assessment, speakers for classes or events, and faculty issues and resources (Cuninggim, 1985; Kaupins \& Coco, 2002; Teitel, 1995; Conroy, Lefever, \& Withian, 1996). Having 
an advisory council also presents a number of challenges. Forming and maintaining an advisory council requires time and effort that may not be valued by the institution (Teitel, 1995). Faculty may oppose or resist the council's recommendations (Cuninggim, 1985; AACSB, 2000). The advisory council may be underutilized for several reasons, including not clearly identifying the role of the council (AACSB, 2000) or spending too much meeting time on college updates and progress reports and not allowing enough time for council members to discuss issues and provide insights or share their experience (Flynn, 2002).

Given the recommendation that advisory councils be used as a bridge between business colleges and the business world, a number of questions arise regarding how the councils are put into place. How prevalent are advisory councils in colleges of business? How many members are on the typical advisory council and what is the composition of the membership? What procedures are followed by the advisory council, including number of meetings per year, location of meetings, length and number of terms of membership? What issues are discussed by the advisory council and how effective is the council perceived to be in addressing these issues? How prevalent is member participation in such activities as financial support, fundraising, and speaking for classes or events? What other activities are associated with council meetings?

A review of the literature revealed some anecdotal evidence in answer to these questions. Comments by deans of various business colleges on their experiences with advisory councils are included in both of the AACSB (2007, 2000) articles, and Flynn (2002) shares her experiences and perspectives on advisory councils as a former dean. There is little research, however, on the utilization of business advisory councils. Flynn (2002, 41) comments, "With advisory councils so important to a school's development, it's surprising that so little has been written to help reduce the amount of 'trial and error' and 'reinvention of the wheel' phenomena associated with bschool BACs." Kaupins \& Coco (2002) surveyed business school administrators at both the college and departmental levels and provide valuable data on advisory councils; however, the composition and utilization of advisory councils may differ at the college level versus the departmental level. Little, Tuckman, \& Humphrey (2000) studied the membership of a single business advisory council to determine methods to most effectively utilize board members to advocate its programs to the local business community.

To gather data on the composition and use of business advisory councils across the country and to provide a comprehensive overview, a survey questionnaire was mailed to a total of 413 business colleges at universities in the United States identified as having business accreditation from The Association to Advance Collegiate Schools of Business (AACSB) International. There were 197 questionnaires returned for a $47.7 \%$ response rate.

\section{RESULTS}

\section{Demographics}

Demographic information is disclosed in Table 1. Of the 197 total respondents, 194 (98.5\%) indicated they had an advisory council for their college. While it is assumed that the sample is representative of the population, it is possible that those colleges with advisory councils may have been more likely to respond to the survey, leading to a higher percentage than may be present in the population. A total of 131 respondents (66.5\%) had AACSB business accreditation only while 66 respondents (33.5\%) had separate accreditation for their Accounting program in addition to their business accreditation.

The degrees offered are categorized by bachelors only, bachelors and masters, bachelors and masters and Ph.D., masters only, and masters and Ph.D. Over half of respondents (58.8\%) reported offering bachelors and masters degrees, while another $23.2 \%$ offered a combination of bachelors, masters, and Ph.D. degrees. The size of the total faculty in the college ranged from 0 to 400 with a median of 60 . The number of tenure-track faculty ranged from zero to 230 with a median of 49 . The size of the faculty at the majority of schools was between 20 and 80 . 
Table 1: Demographics

\begin{tabular}{|c|c|c|c|c|c|}
\hline \multicolumn{4}{|l|}{ Question } & Number & Percent \\
\hline \multicolumn{4}{|c|}{ College of Business Advisory Council? Yes } & 194 & $98.5 \%$ \\
\hline \multicolumn{4}{|c|}{ No } & 3 & $1.5 \%$ \\
\hline \multicolumn{4}{|c|}{ AACSB without separate Accounting accreditation } & 131 & $66.5 \%$ \\
\hline \multicolumn{4}{|c|}{ AACSB with separate Accounting accreditation } & 66 & $33.5 \%$ \\
\hline \multirow[t]{5}{*}{ Degrees offered in college: } & \multicolumn{3}{|l|}{ Bachelors only } & 20 & $10.3 \%$ \\
\hline & \multicolumn{3}{|l|}{ Bachelors and Masters } & 114 & $58.8 \%$ \\
\hline & \multicolumn{3}{|c|}{ Bachelors, Masters, and Ph.D. } & 45 & $23.2 \%$ \\
\hline & \multicolumn{3}{|c|}{ Masters and Ph.D. } & 6 & $3.1 \%$ \\
\hline & \multicolumn{3}{|l|}{ Other } & 9 & $4.6 \%$ \\
\hline \multirow{2}{*}{\multicolumn{2}{|c|}{$\begin{array}{l}\text { Faculty: } \\
\text { Number of faculty: Median }\end{array}$}} & \multicolumn{2}{|c|}{ Total Faculty } & \multicolumn{2}{|c|}{ Tenure-Track Faculty } \\
\hline & & 60 & & 49 & \\
\hline \multicolumn{2}{|c|}{ Distribution of faculty size: Less than 20 faculty } & 10 & $5.2 \%$ & 20 & $10.5 \%$ \\
\hline & $20-39$ faculty & 50 & $26.2 \%$ & 55 & $29.0 \%$ \\
\hline & 40 - 59 faculty & 32 & $16.8 \%$ & 42 & $22.1 \%$ \\
\hline & $60-79$ faculty & 31 & $16.2 \%$ & 36 & $18.9 \%$ \\
\hline & 80 - 99 faculty & 29 & $15.2 \%$ & 24 & $12.7 \%$ \\
\hline & $100-119$ faculty & 16 & $8.4 \%$ & 8 & $4.2 \%$ \\
\hline & $120-139$ faculty & 12 & $6.2 \%$ & 3 & $1.5 \%$ \\
\hline & 140 or more faculty & 11 & $5.8 \%$ & 2 & $1.1 \%$ \\
\hline
\end{tabular}

Table 2: Advisory Council Composition

\begin{tabular}{|c|c|c|c|c|c|}
\hline \multirow{2}{*}{\multicolumn{2}{|c|}{ Council Composition: }} & \multicolumn{4}{|c|}{ Range } \\
\hline & & Mean & Median & Min & Max \\
\hline \multicolumn{2}{|l|}{ Number of members } & 34.4 & 27 & 6 & 450 \\
\hline \multicolumn{2}{|c|}{ Distribution of Council Size: } & Number & Percent & & \\
\hline \multirow[t]{8}{*}{ Number of councils with: } & less than 10 members & 4 & $2.1 \%$ & & \\
\hline & 10 - 19 members & 44 & $22.9 \%$ & & \\
\hline & $20-29$ members & 55 & $28.6 \%$ & & \\
\hline & $30-39$ members & 41 & $21.4 \%$ & & \\
\hline & 40 - 49 members & 20 & $10.4 \%$ & & \\
\hline & 50 - 59 members & 12 & $6.3 \%$ & & \\
\hline & 60 - 99 members & 10 & $5.2 \%$ & & \\
\hline & 100 or more members & 6 & $3.1 \%$ & & \\
\hline \multicolumn{2}{|c|}{ (l) } & Mean & Median & Min & Max \\
\hline \multicolumn{2}{|l|}{ Gender of members: Female } & $19.5 \%$ & $16.7 \%$ & $0 \%$ & $100 \%$ \\
\hline \multicolumn{2}{|c|}{ Male } & $81.5 \%$ & $83.3 \%$ & $0 \%$ & $100 \%$ \\
\hline \multicolumn{2}{|c|}{ Percentage of non-alumni members } & $44.6 \%$ & $44.4 \%$ & $0 \%$ & $100 \%$ \\
\hline
\end{tabular}

\section{Composition}

Responses to questions regarding the composition of advisory councils are summarized in Table 2 . The size of advisory councils ranged widely from 6 members to 450 members, with a mean council size of 34.4 members and median of 27 members. The distribution of the council size indicates the most common council size was in the range of 20-29 members with 55 respondents for $28.6 \%$. The council membership was drawn primarily from industry with $90 \%$ of respondents reporting council members from industry. Approximately half of respondents reported having council members from CPA firms and nearly $42 \%$ of councils had members from government. There appeared to be little involvement by faculty and students, with $82 \%$ of respondents reporting no faculty members and $87 \%$ reporting no students as members of the council. With regard to gender, $83.3 \%$ of council 
members were male and $16.7 \%$ female on average. The majority of council members were alumni of the institution with an average of $44.6 \%$ non-alumni council members.

\section{Council Procedures and Other Activities}

In Table 3, information is given regarding council procedures, other activities associated with council meetings, and location of council meetings. The number of times councils meet per year ranges from one to ten meetings per year, with a mean of 2.48 and median of 2 meetings per year. The median length of membership term on the council was 3 years, which was also the most common response with 123 of 176 respondents for $69.9 \%$. A number of respondents (26 of 176 for 14.8\%) indicated the length of membership was "indefinite" or "no limit." Virtually all (98.7\%) of respondents indicated that council members can be reappointed, with a majority (95 of 144 for $66 \%$ ) responding that there is no limit on the number of times a council member can be reappointed. Slightly less than three-fourths (73.3\%) of respondents had a written mission statement for their council while $61.8 \%$ had written procedures or bylaws.

Table 3: Council Procedures and Other Activities

\begin{tabular}{|c|c|c|c|c|}
\hline \multirow{2}{*}{ Council Procedures: } & \multicolumn{4}{|c|}{ Range } \\
\hline & Mean & Median & Min & Max \\
\hline Number of meetings per year & 2.48 & 2 & 1 & 10 \\
\hline Length of membership term & $\mathrm{N} / \mathrm{A}^{\mathrm{a}}$ & 3 & 1 & indefinite \\
\hline If fixed term, can member be reappointed? Yes & $98.7 \%$ & & & \\
\hline Reappointed how many times? & $\mathrm{N} / \mathrm{A}^{\mathrm{a}}$ & indefinite & 1 & indefinite \\
\hline Written mission statement? Yes & $73.3 \%$ & $26.7 \%$ & & \\
\hline Written procedures? Yes & $61.8 \%$ & $38.2 \%$ & & \\
\hline $\begin{array}{l}\text { Other activities associated with Council meetings? } \\
\text { (Percentage of respondents indicating "yes") }\end{array}$ & Mean & & & \\
\hline Social function (e.g. dinner) & $87.7 \%$ & & & \\
\hline Fund raising & $86.2 \%$ & & & \\
\hline Reception & $80.8 \%$ & & & \\
\hline Athletic event & $41.7 \%$ & & & \\
\hline Golf Outings & $41.6 \%$ & & & \\
\hline Spouse events & $31.5 \%$ & & & \\
\hline Homecoming & $29.1 \%$ & & & \\
\hline Tours of businesses & $19.9 \%$ & & & \\
\hline \multicolumn{2}{|l|}{ Council member participation in: } & & & \\
\hline Financial support? & $90.7 \%$ & & & \\
\hline Is financial support a requirement to be on the Council? & $30.0 \%$ & & & \\
\hline Assistance in fund raising? & $91.7 \%$ & & & \\
\hline Assistance in outcome assessment? & $68.6 \%$ & & & \\
\hline Speakers for classes or other events? & $96.3 \%$ & & & \\
\hline Speakers for student organizations? & $88.9 \%$ & & & \\
\hline
\end{tabular}

Respondents were asked where council meetings were held. The most common location for council meetings was on the university's campus, with a mean of $81.8 \%$ and median of $100 \%$ of council meetings held on campus. Sixty-five percent of respondents indicated that $100 \%$ of their council meetings were held on campus.

In addition to the council meeting, respondents were asked what, if any, other activities were associated with their council meetings, such as social functions or fund raising. Virtually all respondents (95\%) indicated they did have other activities associated with council meetings. The most commonly reported activity associated with council meetings was social functions (e.g. dinner) with $87.7 \%$ of respondents indicating a positive response, followed closely by fund raising $(86.2 \%)$ and reception $(80.8 \%)$. Less commonly reported activities included 
athletic event (41.7\%), golf outing (41.6\%), spouse events (31.5\%), homecoming (29.1\%), and tours of businesses $(19.1 \%)$.

When asked whether council members provide assistance in various activities such as fundraising or speaking for classes, respondents indicated a high level of council member participation. Respondents reported council member participation in providing financial support (90.7\%), assistance in fund raising $(91.7 \%)$, speakers for classes or other events (96.3\%) or for student organizations (88.9\%), and outcome assessment (68.6\%). While a high percentage of respondents indicated that council members provide financial support, only a small percentage (30\%) indicated that financial support was a requirement to be on the council.

Table 4: Advisory Council Participation

\begin{tabular}{|c|c|c|c|c|}
\hline Item of Discussion & $\begin{array}{l}\%^{1} \\
\text { Yes }\end{array}$ & Rank & $\begin{array}{l}\text { Effectiveness }^{2} \\
\text { Mean }\end{array}$ & Rank \\
\hline Strategic planning & $97.9 \%$ & 1 & 4.24 & 1 \\
\hline College or program mission statement & $97.4 \%$ & 2 & 4.15 & 3 \\
\hline Curriculum issues & $92.7 \%$ & 3 & 3.70 & 12 \\
\hline Speakers for classes or other events & $91.6 \%$ & 4 & 4.23 & 2 \\
\hline Fund raising & $90.7 \%$ & 5 & 3.91 & 5 \\
\hline Accreditation issues faced by the college & $88.9 \%$ & 6 & 3.76 & 9 \\
\hline Financial support for college needs & $88.4 \%$ & 7 & 3.88 & 6 \\
\hline Placement of graduates & $87.0 \%$ & 8 & 3.72 & 11 \\
\hline Student internships & $84.5 \%$ & 9 & 3.78 & 8 \\
\hline Speakers for student organizations & $81.9 \%$ & 10 & 4.05 & 4 \\
\hline Financial support for student scholarships & $78.3 \%$ & 11 & 3.87 & 7 \\
\hline College development campaign & $76.8 \%$ & 12 & 3.75 & 10 \\
\hline Development of a college brand & $71.1 \%$ & 13 & 3.61 & 13 \\
\hline Outcome assessment & $70.1 \%$ & 14 & 3.37 & 16 \\
\hline Executive in Residence Programs & $64.4 \%$ & 15 & 3.61 & 14 \\
\hline Naming opportunities for the college, departments, or programs & $62.1 \%$ & 16 & 3.32 & 17 \\
\hline Financial support for endowed chair(s) (professors or fellows) & $59.6 \%$ & 17 & 3.39 & 15 \\
\hline Facilitating faculty research & $59.1 \%$ & 18 & 2.80 & 20 \\
\hline International programs or affiliations & $56.4 \%$ & 19 & 3.12 & 18 \\
\hline Faculty internships & $48.2 \%$ & 20 & 2.76 & 21 \\
\hline Development of the college honor code of ethics & $26.8 \%$ & 21 & 3.0 & 19 \\
\hline Change of name for the college & $18.9 \%$ & 22 & 2.49 & 23 \\
\hline Training opportunities for council members & $17.0 \%$ & 23 & 2.51 & 22 \\
\hline Evaluating faculty research & $13.0 \%$ & 24 & 1.80 & 25 \\
\hline Financial support for faculty sabbaticals & $10.4 \%$ & 25 & 2.18 & 24 \\
\hline
\end{tabular}

${ }^{1}$ Percentage of respondents indicating that the item is discussed by their advisory council.

${ }^{2}$ Effectiveness is on a scale of 1 (not effective) to 5 (very effective).

\section{Items of Discussion and Effectiveness}

Table 4 summarizes the responses to questions regarding the issues discussed by the advisory council and the perceived or potential effectiveness of the council in addressing the issues. Respondents were asked whether the issues listed in Table 4 were currently being discussed at advisory council meetings. They were then asked to rate the perceived effectiveness of the council in addressing the issue if they answered yes, or the potential effectiveness if they answered no, on a scale of 5 (very effective) to 1 (not effective).

The results in Table 4 reveal that the issues with the highest positive responses were strategic planning and college or program mission statement, with $97.9 \%$ and $97.4 \%$, respectively, of respondents indicating these issues were currently being discussed by their council. Other issues in the top five with over $90 \%$ positive response were curriculum issues $(92.7 \%)$, speakers for classes or other events (91.6\%), and fund raising (90.7\%). The next seven items were also being discussed by over $75 \%$ of councils, including accreditation issues faced by the college 
(88.9\%), financial support for college needs (88.4\%), placement of graduates (87.0\%), student internships (84.5\%), speakers for student organizations (81.9\%), financial support for student scholarships (78.3\%), and college development campaign (76.8\%). The next seven items were discussed by a majority (over 50\%) of councils. These items included development of a college brand $(71.1 \%)$, outcome assessment $(70.1 \%)$, Executive in Residence programs $(64.4 \%)$, naming opportunities for the college, departments, or programs $(62.1 \%)$, financial support for endowed chairs (59.6\%), facilitating faculty research $(59.1 \%)$, and international programs or affiliations (56.4\%). The remaining six items were under discussion by less than half the councils, including faculty internships (48.2\%), development of the college honor code of ethics (26.8\%), change of name for the college (18.9\%), training opportunities for council members (17.0\%), evaluating faculty research (13\%), and financial support for faculty sabbaticals (10.4\%). It is interesting to note that those items discussed by over $75 \%$ of councils dealt primarily with administrative issues or curriculum and student issues. The least discussed items dealt with faculty issues, with the most discussed faculty issue (financial support for endowed chairs) at $59.6 \%$. It was also interesting to note that while international programs and ethics are fairly recent trends in business curriculums, these issues are not widely discussed by advisory councils, with $56.4 \%$ of councils reporting discussing international programs and only $26.9 \%$ discussing development of the college honor code of ethics. It is possible, however, that many colleges of business already have these programs in place so that they are not currently being discussed by the council.

The perceived or potential effectiveness of the council in addressing these items did not necessarily correspond with the frequency of discussion, although the groupings were similar. Not surprisingly, councils were perceived as being most effective in addressing those items discussed by over $75 \%$ of councils (about half the items listed in Table 4), while councils were perceived as least effective in addressing the lesser-discussed items. However, the perceived effectiveness varied within those groups as revealed by a comparison of their rankings. For example, speakers for student organizations was not one of the most highly-discussed items at $81.9 \%$ but ranked fourth in perceived effectiveness at 4.05 on a 5-point scale. This would make sense given that board members are likely happy to speak when asked and would not require discussion by the council. On the other hand, while curriculum issues ranked third in terms of discussion at $92.7 \%$, councils were perceived as being only moderately effective with a mean of 3.7 on a 5-point scale. This result would appear to support the comments by AACSB (2000) that "getting faculty to listen to advisors" was one of the challenges of advisory councils. Likewise, Cuninggim $(1985,7)$ noted that, "Many faculty members do not take kindly to the idea that an outside group might mess around in the curriculum." For the remaining items, the frequency of discussion and perceived effectiveness were similar. Similar to the frequency of discussion, councils were viewed as most effective in addressing issues relating primarily to the administration and students and least effective in addressing faculty issues.

\section{Opinions on Statements}

Finally, respondents were asked to express their opinions on two statements on a 5-point scale ranging from strongly agree (5) to strongly disagree (1). They were also asked to indicate how their institution values faculty time and energy devoted to an advisory council for tenure, promotion, merit pay, and service considerations on a 5-point scale ranging from high value (5) to no value (1). The results are presented in Table 5. Respondents agreed strongly that "the use of an advisory board shows that the college is serious about maintaining a relationship with the business profession" with $92.8 \%$ strongly agree/agree (SA/A) and a mean of 4.61 . Respondents did not agree as strongly with the second statement, "The end result of participation with an advisory council must be a payoff in student learning." The mean was 3.71 on a 5-point scale, and $56.9 \%$ of respondents agreed (SA/A) while another $28.7 \%$ were neutral.

Respondents believed that faculty time and energy spent on involvement with an advisory council carried little or no value for tenure (88.6\% total of little or no value), promotion (84\%), and merit pay (85.7\%) with means of 1.82, 1.88, and 1.93, respectively, on a 5-point scale. The value for service was slightly higher with a mean of 2.3 but still $58.5 \%$ of respondents placed little or no value on such service. 
Table 5: Opinions on Statements

Respondents' extent of agreement with the following two statements ranging from strongly agree (5) to strongly disagree (1). Statement 3 indicates the value placed on faculty involvement with an advisory council from High Value to No Value for purposes of tenure, promotion, merit pay, and service.

\begin{tabular}{|l|c|c|c|c|c|c|}
\hline Statement & Mean & SA & A & N & D & SD \\
\hline $\begin{array}{l}\text { 1. The use of an advisory council shows that the } \\
\text { college is serious about maintaining a relationship } \\
\text { with the business profession. }\end{array}$ & 4.61 & $70.5 \%$ & $22.3 \%$ & $5.2 \%$ & $1.6 \%$ & $0.5 \%$ \\
\hline $\begin{array}{l}\text { 2. "The end result of participation with an advisory } \\
\text { council must be a payoff in student learning." }\end{array}$ & 3.71 & $33.0 \%$ & $23.9 \%$ & $28.7 \%$ & $9.6 \%$ & $4.8 \%$ \\
\hline $\begin{array}{l}\text { 3. How does your institution value the expenditure of } \\
\text { faculty time and energy involved with an advisory } \\
\text { council with regards to: }\end{array}$ & Mean & $\begin{array}{c}\text { High } \\
\text { Value }\end{array}$ & & & & No \\
\hline a. Tenure & 1.52 & $1.1 \%$ & $2.7 \%$ & $7.6 \%$ & $24.3 \%$ & $64.3 \%$ \\
\hline b. Promotion & 1.63 & $1.6 \%$ & $3.7 \%$ & $10.7 \%$ & $24.1 \%$ & $59.9 \%$ \\
\hline c. Merit pay & 1.57 & $1.6 \%$ & $3.3 \%$ & $9.3 \%$ & $22.0 \%$ & $63.7 \%$ \\
\hline d. Service & 2.30 & $6.4 \%$ & $17.6 \%$ & $17.6 \%$ & $16.5 \%$ & $42.0 \%$ \\
\hline
\end{tabular}

\section{SUMMARY}

This study was conducted to gather data on the composition and utilization of business advisory councils. The results reveal that virtually all business schools responding to the survey had an advisory council. The median advisory council had 27 members composed primarily of members from industry and meets two times per year, primarily on the university's campus. The median length of board term was 3 years with no limit on the number of times a member may be reappointed.

The items most commonly discussed by advisory councils included administrative issues such as strategic planning, mission statement, and fundraising, and student-related issues such as curriculum and speakers for classes. The least commonly discussed items were faculty-related issues such as evaluating faculty research and financial support for sabbaticals. The perceived or potential effectiveness of advisory councils was also highest for administrative and student-related issues and lowest for faculty-related issues, although the order of effectiveness did not necessarily correspond with the order of discussed items. Board members tended to participate or assist in a number of the issues, including financial support and fundraising and speaking for classes or student organizations.

Finally, there was strong agreement with the statement that having an advisory council signals a desire to maintain a relationship with the business world, but less agreement with the statement regarding a "payoff in student learning." Involvement by faculty with an advisory council was viewed as having little or no value for tenure, promotion, merit pay, and service considerations.

The results of this survey support the anecdotal evidence that business advisory councils are widespread and provide an important link between business colleges and the business world. As noted by the AACSB (2000), “...the role of advisory councils - as advocates, ambassadors and a reality touchstone - will remain critical and likely become more so as business continues rapid change."

\section{AUTHOR INFORMATION}

Dee Ann Ellingson, Ph.D., CPA, is Associate Professor of Accounting at the University of North Dakota. She received her Ph.D. in accounting from Virginia Tech. Her research is primarily in management accounting and accounting education. She is past-president of the North American Accounting Society and is on the advisory council of the MBAA-International.

Dennis Elbert, Ph.D., is Dean of the College of Business \& Public Administration and Professor of Marketing at the University of North Dakota. He received his Ph.D. from the University of Missouri - Columbia. He has published articles in a number of journals, including Services Marketing Quarterly (formerly Journal of 
Professional Services Marketing), Management Research News, Journal of Entrepreneurship, Journal of Small Business Management, Swiss Research Institute Journal of Small Business, Journal of Marketing Education, and SBI Review.

Steven Moser, Ph.D., is Associate Dean of the College of Business \& Public Administration and Professor of Management at the University of North Dakota. He earned his Ph.D. from the University of Cincinnati. Dr. Moser's research work has been published in the Journal of Small Business Management, Journal of Entrepreneurship Education, Public Personnel Management, International Journal of Organizational Analysis, Journal of Education for Business, Journal of Applied Business Research, Entrepreneurship and Regional Development, Journal of Individual Employment Rights, and Journal of International Information Management.

\section{REFERENCES}

1. Association to Advance Collegiate Schools of Business-International (AACSB). (2000, Summer). Business Schools Look to Their Advisory Boards for Reality Check. Newsline. Retrieved October 15, 2007 from http://www.aacsb.edu/publications/printnewsline/NL2000/smreality.asp

2. Association to Advance Collegiate Schools of Business-International (AACSB). (2007, September/October). Advise and Connect. BizEd, 24-30.

3. Conroy, P. A., Lefever, M. M., \& Withian, G. (1996, August). The Value of College Advisory Boards. Cornell Hotel \& Restaurant Quarterly, 37, 85-89.

4. Cuninggim, M. (1985). The Pros and Cons of Advisory Committees. Washington, DC: Association of Governing Boards of Universities and Colleges.

5. $\quad$ Flynn, P. M. (2002, November/December). Build the Best BAC. BizEd, 40-44.

6. Kaupins, G., \& Coco, M. (2002, Winter). Administrator Perceptions of Business School Advisory Boards. Education, 123, 351-357.

7. Lerner, M. J. (1990, August). The Effective Use of Advisory Committees. Career Training, 7, 19-22.

8. Little, M. W., Tuckman, H., \& Humphrey, R. (2000). Marketing for Involvement Advocacy: Business Advisory Boards - A Case Study. Journal of Professional Services Marketing, 21, 117-124.

9. Teitel, L. (1995, Summer/Fall). Using Advisory Committees Effectively in Higher Education. Journal for Higher Education Management, 11, 59-70.

10. Vazzana, G., Elfrink, J., \& Bachmann, D. P. (2000, November/December). A Longitudinal Study of Total Quality Management Processes in Business Colleges. Journal of Education for Business, 76, 69-74. 